Article

\title{
Theorising Disability Care (Non-)Personalisation in European Countries: Comparing Personal Assistance Schemes in Switzerland, Germany, Sweden, and the United Kingdom
}

\author{
Christoph Tschanz \\ Division of Sociology, Social Policy and Social Work, University of Fribourg, 1700 Fribourg, Switzerland; \\ E-Mail: christoph.tschanz@unifr.ch
}

Submitted: 19 December 2017 | Accepted: 6 February 2018 | Published: 17 May 2018

\begin{abstract}
This article examines four European countries (Switzerland, Germany, Sweden, and the United Kingdom) with respect to their degree of disability care personalisation. The approach is embedded in a broader theoretical analysis, which in turn is inspired by the notion of bivalent social justice as presented by Nancy Fraser (2003). The theoretical argument is that claims for personal assistance are part of a broader movement toward emancipation. However, it is argued that the specific settings of welfare regimes provide structures that empower or mitigate the possible implementation of personal assistance schemes. The author argues that conservative-corporatist welfare regimes provide less-supportive opportunity structures for policy change pertaining to personal assistance than other welfare regimes. This heuristic argument is developed further by looking more closely at key figures of Sweden, Germany, and the United Kingdom as being ideal-typical welfare regime cases. Furthermore, the case of Switzerland is outlined in an in-depth manner as it seems to have conservativecorporatist characteristics regarding the organisation of disability care while simultaneously being difficult to theorise. It is the aim of this article to serve as a first heuristic undertaking for analysing the low level of disability care personalisation in certain continental European cases.
\end{abstract}

\section{Keywords}

comparative social policy; disability care; Nancy Fraser; personal assistance; personalisation; social movements; social services; social stratification; Switzerland; welfare state regimes

\section{Issue}

This article is part of the issue "Global Perspectives on Disability", edited by Shaun Grech (The Critical Institute, Malta) and Karen Soldatic (Western Sydney University, Australia).

(C) 2018 by the author; licensee Cogitatio (Lisbon, Portugal). This article is licensed under a Creative Commons Attribution 4.0 International License (CC BY).

\section{Introduction}

In recent years, some countries have de-institutionalised their residential disability care facilities. An emerging central idea is the organisation of disability care through personal assistance. This phenomenon has been most pronounced in the United States of America, Canada, Australasia, and-in the European context-Scandinavia and the United Kingdom (Mansell \& Beadle-Brown, 2010, p. 104). Personal assistance is characterised by the direct funding of disabled people instead of the service provider and by the person's freedom to choose the desired services (Ratzka, 2004, pp. 2-3). The policy change in disability services to personal assistance, instead of residential care (hereinafter, personalisation), is key to enable independent living. Although the term 'personalisation' is used ambiguously in the United Kingdom's recent political practice (Beresford, 2014, pp. 5-6), for simplification purposes this article uses the term in its original meaning as direct payments for personal assistance (Slasberg \& Beresford, 2015, p. 481). Personal assistance liberates the impaired person from the role of a passive care recipient and makes the person a "customer or boss" (Ratzka, 2004, p. 3).

In the extant literature, only a few studies (Aselmeier, 2008; Aselmeier \& Weinbach, 2004; Baumgartner, 2009, 2008; Rimmerman, 2017; Rummery, 2011; Šiška, BeadleBrown, Káňová, \& Tøssebro, 2017; Waterplas \& Samoy, 
2005; Wemßen, 2014) compare disability care and living arrangements by including continental European countries. What is more, there are also reports (ANED, 2009; BSV, 2007; ENIL, 2017b; ESN, 2013; FRA, 2013) comparing countries of different sets of geographical origin. Nevertheless, to the best of my knowledge, there is a need for the proliferation of social-theory-grounded comparative insights regarding continental European countries.

Some continental European countries seem to show greater reluctance toward personalisation than AngloSaxon and Scandinavian countries. I address this issue through a comparative social-policy perspective by including the cases of Germany and Switzerland. In both cases, the policy change from residential care to personal assistance occurred to a more limited extent than within the European personalisation-pioneer countriesSweden and the United Kingdom. The article drafts a theoretical framework in which all four countries can be compared. This analysis is embedded in a broader theoretical approach of welfare and disability theories and aims to make the first theoretical illustration for a possible framework for comparing these diverse cases by understanding the continental European cases particularly.

Following the introduction, the second part of this article lays out a possible understanding of personalisation, drawing on an overarching social theory framework. As Richardson and Powell (2011, p. 75) point out, the works of Marshall (1950) and Polanyi (1944/2001) are well-suited to provide an understanding of the underlying dynamics, which lead to similar events in countries that are otherwise quite dissimilar (for an application of Marshall, 1950, to personal assistance see: Christensen, Guldvik, \& Larsson, 2014). These very well-known metatheoretical argument classics are combined with the insights of Nancy Fraser (2013) as well as Fraser and colleagues (Fraser \& Honneth, 2003). It is a central claim of this article that the bivalent understanding of social justice given by Nancy Fraser is highly fruitful for this theoretical undertaking. Within this understanding, a genuine disability theory (Drake, 1999) is included. The aim of the second part of this article is to provide a narrative for underlying dynamics that are similar in all four countries included in this comparison. The claims for personal assistance are seen as a typical claim of an emancipatory movement, given a special framework within the bivalent understanding of social justice.

The third part of this article has a slightly different aim-it attempts to provide an explanation for the more reluctant implementation of personal assistance in the two continental European countries in this comparison, and therefore tries to explain the dissimilarities in policy outcome, despite the similar claims of the emancipatory disability movement. These dissimilarities are explained with two theories - the power resource theory and corporatism theory - which are related, according to Ebbinghaus (2015), by being genuine conflict theories. Ebbinghaus $(2015$, p. 55$)$ points out that one important contribution of the power resources theory applied to social policy is The Three Worlds of Welfare Capitalism by Gøsta Esping-Andersen (1990). This framework, which assumes different welfare regimes, is applied to explain dissimilarities regarding personalisation within the four compared countries and is combined with a somewhat bigger theoretical framework of disability rights. The insights about disability rights in the second part are combined with insights about welfare regimes in the third part in order to understand the dissimilarities.

In the fourth part, a more in-depth analysis is generated regarding the four countries. The United Kingdom, Sweden, and Germany are taken as ideal-typical cases for three different welfare regimes. Key figures about social spending and the amount of people receiving personal assistance are compared. Furthermore, Switzerland provides a challenge for regime theory because it shows key figures of the conservative-corporatist case in disability care contradicting its classification in welfare regime typology. Ciccia (2017) points out that one can overcome some limitations of regime theory by combining welfare regime macro theorising with an in-depth analysis of disaggregated concrete policies. This approach is conducted with the Swiss case in a single case study. Looking closer at Switzerland, one detects that the organisation and governance of social service in the disability sector is another key factor for theorising. So, following the insights of disability rights and the insights of welfare regimes, the insights of the organisation of social services completes the argumentative picture.

The fifth part is the conclusion. In the conclusion, the interplay of disability rights, welfare regime, and the organisation of social services are summarised again. The main aim of this article is to develop a heuristic approach to incorporate a continental European view within comparative studies about personalisation. This article attempts to make an illustrative argument that may be useful for more concrete empirical investigations in the future.

\section{A Fraserian Perspective on Welfare and Disability Rights}

\subsection{The Bivalent Nature of Social Justice}

The theory proposed by critical theorist Nancy Fraser can be very fruitful for disability policy analyses (for analyses in the Western capitalist context: Dodd, 2016; Knight, 2015; Mladenov, 2016; for analyses in the global context: Soldatic, 2013; Soldatic \& Grech, 2014; for care policy: Swaton, 2017; for personal assistance: Mladenov, 2012; Mladenov, Owens, \& Cribb, 2015; Owens, Mladenov, \& Cribb, 2017). According to Fraser (2003), there are generally two dimensions of social justice: recognition justice and redistributive justice. The former corresponds to status-based disadvantage while the latter corresponds to socio-economic class hierarchy. In a plausible expression, the aim of redistributive justice is material egalitarianism while the aim of recognition justice 
is societal diversity (Fraser, 2003, p. 7). Redistributive justice is characterised by a more just distribution of income and wealth, while with recognition justice one does not have to pay the price of assimilation to gain equal respect (Fraser, 2003, p. 7). Applied to personalisation, this means:

Fraser's two-dimensional framework implies that personalisation's potential for contributing toward social justice depends on its ability to bring together redistribution and recognition in ways that, first, guarantee the economic resources needed by service users for equal participation in social life (thus satisfying concerns about redistribution), and second, institutionalise patterns of cultural interpretation that equalise the status of service users in social interaction (thus satisfying the principle of recognition). (Owens et al., 2017, p. 8)

I mainly claim that one can achieve a fruitful link between welfare theory and disability theory by standing on the shoulders of Nancy Fraser, but this needs a constructive contention of two existing theories pertaining to the bivalent framework.

\subsection{The Works of Marshall and Drake through the Bivalent Perspective}

In the research field of the welfare state, the essay Citizenship and Social Class by T. H. Marshall (1950) is very well-known. Marshall (1950) analyses the attributions that individuals can receive in markets and compares these to the attributions that one can get as a citizen. He describes a partial withdrawal of individuals from purely market-shaped assignments toward a citizenship with social rights. The evolution of rights can be studied in different phases - the development of civil rights in the 18th century, political rights in the 19th century, and social rights in the 20th century (Marshall, 1950). On the other hand, Drake (1999) espouses a genuine disability theory and distinguishes between the different models of disability policies that can be observed in history. The laissez-faire model is characterised by the fact that the state plays a minimal role in the lives of disabled people (Drake, 1999, pp. 36-37). In this case, the burden of care falls on communities or on households and families (Budowski \& Schief, 2017). The piecemeal approach to policy-making is characterised by the broad adoption and application of the medical model of disability; people are classified and categorised according to their impairments and the state responds to the needs of the disabled people (Drake, 1999, pp. 36-37). In the maximal policy model, the state starts to combat structural inequalities linked with disability and develops welfare responses to combat these disparities (Drake, 1999, pp. 36-37). The social or rights-based model is characterised by the fact that disability is more than a welfare issue (Drake, 1999, pp. 36-37). In this model, the state accepts disablement to be a product of society itself and accepts responsibility to serve all its citizens (Drake, 1999, p. 36). In this case, the social model of disability is fully accepted and serves as the main guide for disability policy-making.

I make the case that the difference between the theories of Marshall (1950) and Drake (1999) seems to be basically a difference in succession between the two different kinds of justice described by Nancy Fraser. This idea is inspired by a comparative educational idea of Richardson and Powell (2011, p. 76), which asserts that special education also did not follow a "benign linearity" directly from exclusion to inclusion (Richardson \& Powell, 2011, p. 76). Rather, it started as a (distributive) support and service scheme for people who were totally excluded from public schooling while the new (recognition-oriented) societal norms of participation occurred later in its history (Richardson \& Powell, 2011, p. 76). Long before the turning point to 'inclusive education', the school system was-and in many cases still ischaracterised by supportive but non-inclusive 'special education' (Powell, 2006).

In this article, I make the fundamental claim that both theories (Drake, 1999; Marshall, 1950) lack the narrative of linearity within the framework of bivalent justice. As shown in Figure 1, both form a curve in which one kind of justice is first adopted more strongly, provoking later claims to fulfil the other part of social justice. One can understand the narrative of Marshall (1950) as that of an increase in recognition justice followed by an increase in redistributive justice: in the 18th and 19th centuries, the burgeoning class of male workers gained recognition and rights. This triggered claims for redistributive policies, which were applied as social rights in the 20th century. In contrast, Drake (1999) puts forth another narrative for the disability policy: first, the redistributive justice is increased with the implementation of welfare states. Thereafter, with a basic social security, impaired people started to claim more civil and political rights to increase recognition justice.

These thoughts are just heuristic and do not completely satisfy the complexity of these two theories. The period of these two theories was different, as were the respective study populations. While Marshall's analysis (1950) describes the development of working-class men over three centuries, Drake's examination (1999) focuses on disabled people and maps different possible cases of disability policy. But the understanding of a conversely arranged development curve can be used as a heuristic tool for approaching the current state of disability care organisation in different welfare regimes because it tells us something about the principal societal tensions.

\subsection{Personal Assistance as a Form of Emancipation}

Within the disability movement, there is the claim that while residential care residents are "well-fed and clean", there is a lack of "inedible" conditions like equality and 


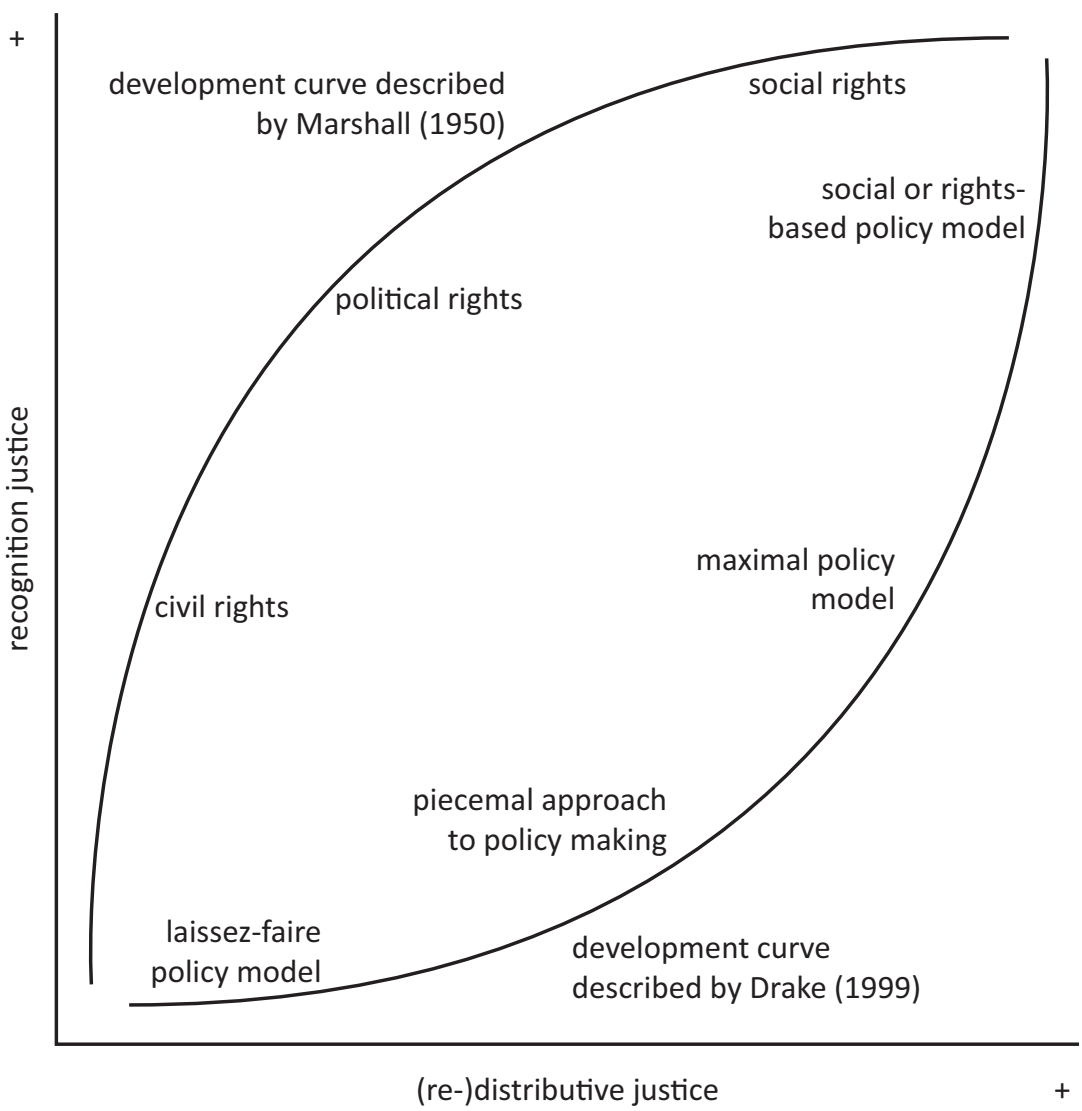

Figure 1. Synthesis of theories to explore disability rights. Source: Adaptation by author, inspired by Fraser (2003, 2013), Marshall (1950), and Drake (1999).

participation (Wehrli, 2016, p. 530). With this criticism, Peter Wehrli, one of the most influential emancipatory disability activists in Switzerland and the former leader of the Centre for Independent Living Zürich, refers to the mode of expression of the emancipatory disability movement (Krüppelbewegung) in Germany. Being "well-fed and clean [satt und sauber]" (Wehrli, 2016, p. 530) is a critical and ironic look at the condition of residential care: it points to the (over-)supply of distributive provisions like food, medical facilities, and hygienic measures, and the under-supply of recognition as an autonomous and free individual.

Drawing and expanding the work of Karl Polanyi (1944/2001), Fraser (2013) explains the current structural and ideological tensions within capitalist democracies as triple movement of marketization, social protection, and emancipation. For Fraser (2013), the new social movements established in recent decades are the main drivers of emancipation:

Often focused more on recognition than redistribution, these movements were highly critical of the forms of social protection that were institutionalized in the welfare and development states of the post-war era. Turning a withering eye on the cultural norms encoded in social provisions, they unearthed invidious hierarchies and social exclusions. (Fraser, 2013, p. 127)
According to Dodd (2016, p. 162), the disability movement is a good example of the triple movement of emancipation because it is critical toward domination through both marketization and social protection. With the triplemovement framework, one can understand current politics in care policy (Swaton, 2017). I make the case that the claims for personal assistance (see e.g., Ratzka, 2004) are emancipatory claims for more recognition justice, pertaining to a situation in which mainly only redistribution justice is provided by the residential care institution. In other words, referring to Figure 1 , the disability movement starts to act in a disability policy situation that lies in the bottom-right quadrant of the square.

\section{Welfare Regime Stratification and (Non-)Personalisation}

\subsection{The Welfare Regime as an Opportunity Structure for Disability Movements}

While the triple movement framework provides valuable insights into the politics of disability care in recent decades, it fails to explain why some countries went for a significant policy change toward personalisation while others show stability by staying stuck in the bottom-right quadrant of the square in Figure 1. I argue that the different degrees of the fulfilment of personal assistance can be explained by welfare regimes (e.g., Esping-Andersen, 
1990). It is assumed that the differences of cases cannot be solely attributed to the emancipatory movement itself but rather one has to also look at the way the welfare regime was set up. Esping-Andersen (1990) provides a coherent explanation of the interwoven nature of actors, ideas, and institutions comprising a welfare regime. This work relies on the power resource theory by explaining the occurrence of a welfare regime due to class conflict (Ebbinghaus, 2015, pp. 55, 70). Ebbinghaus (2015, p. 70) points out that there are also power resource theory applications pertaining to new social movements. I follow the argument that new social movements depend on the political opportunity structures provided by the political system in which they act (see Tarrow, 2011; see for an application of this theory to disability protests: Barnartt \& Scotch, 2001, chapters 6 and 7).

\subsection{Welfare Regimes and (Non-)Opportunities for Claiming Personalisation Rights}

One must ask whether the stratification tradition of a given welfare regime is open to the claiming of personalisation rights of the emancipatory disability movement. I argue that the class structure of a welfare regime is especially formative for the opportunity structure because both the disability movement itself and its claims for personal assistance are characterised by intersections with class. On the one hand, "people with disabilities, at least as a group, may have been the first to join the ranks of the underclass" (Charlton, 2010, p. 149) due to historical oppression. Disabled people face status-reducing effects as a group (Maschke, 2007, p. 299). On the other hand, the disability movement's claims for personal assistance resemble the middle-class claims related to selfdetermination and personal responsibility. Given the situation of a lack of recognition justice, the emancipatory movement claiming middle-class rights therefore strongly implies upward social status aspirations. For Esping-Andersen (1990), the regulation of social stratification is a core element of a welfare regime. According to Esping-Andersen (1990, pp. 29-30) different welfare regimes follow different patterns of how they moderate inequalities between the underclass and the middle class. Recent research shows that welfare regimes can also moderate the effects of status on subjective wellbeing (Samuel \& Hadjar, 2016). In this line, it is assumed that they can empower or mitigate the upward social status aspirations of collective groups.

The ideal-type social democratic regime should provide a sufficient opportunity structure for the emancipatory disability movement. Historically, social-democratic reforms have always aimed to significantly correct the stratification produced by the market (Esping-Andersen, 1990, p. 65). The social democrats found a framework for a middle-class standardised universalism (EspingAndersen, 1990, p. 69) aiming to provide every citizen with middle-class rights. Therefore, the idea of middleclass rights for impaired people fits well with the social- democratic ideal of common equality. Additionally, the ideal-type liberal regime should also provide a sufficient opportunity structure for the emancipatory disability movement. As per liberal thoughts (here, in contrast to social-democratic ideas), it is inappropriate for social policy to significantly correct stratification patterns produced by the marketplace (Esping-Andersen, 1990, p. 62). However, traditional liberal thoughts favour the provision of de jure and pre-market universalism and equality (Esping-Andersen, 1990, p. 62). Hence, the de jure provision of equal rights for disabled people should be achievable within a liberal framework (while post-market redistributive funding, in contrast to the social-democratic ideas, is ideologically under more scrutiny). Mainly in contrast to the other two regimes, the ideal-type conservative-corporatist regime could be an insufficient opportunity structure for the emancipatory disability movement. Stratification in conservative social policy follows the guideline of retaining traditional status relations (Esping-Andersen, 1990, p. 58). This regime is less averse to correct stratification effects caused by the market as compared to the liberal regime (Esping-Andersen, 1990). However, since the conservative-corporatist regime is guided by traditional ideas of status stability, emerging ideas of middleclass rights for impaired people are in danger of being regarded as somewhat at odds. The conservativecorporatist disability policy is characterised by "paternalism" (Waldschmidt, 2009, p. 19) and "benevolent paternalism" (Richardson \& Powell, 2011, p. 184).

\section{Comparing the Four Cases and a Closer Look at Switzerland}

\subsection{Comparing Key Figures: Switzerland as a Challenge for Regime Theory}

Following Aselmeier (2008) and Aselmeier and Weinbach (2004), one can see the United Kingdom as an example of the liberal, Sweden as an example of the social democratic, and Germany as an example of the conservative-corporatist regime. Looking at recent key figures, one can detect major dissimilarities (see Table 1). The data for social spending is derived from the Organisation for Economic Cooperation and Development (OECD). Within the OECD Social Expenditure Database, there is a category called "Public Incapacity-Related Spending", with a sub-category "Benefits in Kind", which in turn has a sub-category "Residential-Care/Home-Help Services" (OECD, 2017a). This category is of great interest because personalised and residential services are measured under one umbrella. Surely, the terminology 'incapacityrelated' can be criticised to follow the medical model of disability. Second, this umbrella measurement does not measure the same policies in all four countries. This umbrella category has further sub-categories, which differ in the four countries. For instance, in 2013, Switzerland spent more than two thirds of this umbrella category on 
Table 1. Key figures of disability care personalisation.

\begin{tabular}{|c|c|c|c|}
\hline Country & Welfare Regime & $\begin{array}{l}\text { Social Spending on } \\
\text { Residential-Care/Home-Help } \\
\text { Services }^{\mathrm{a}} \text { as \%o of GDP }\end{array}$ & $\begin{array}{l}\text { People with Personal } \\
\text { Assistance }^{c} \text { as \%o of } \\
\text { Total Population }^{d}\end{array}$ \\
\hline United Kingdom & liberal & 2.34 & 3.85 \\
\hline Germany & conservative-corporatist & 5.40 & 0.25 \\
\hline Sweden & social-democratic & 16.45 & 2.08 \\
\hline Switzerland & hybrid case & 4.82 & 0.15 \\
\hline
\end{tabular}

Notes: Own calculations, rounded to two decimal places. Data sources: a) OECD Social Expenditure Database (OECD, 2017a); b) OECD National Accounts (OECD, 2017b); c) UK, SE \& CH: ENIL Personal Assistance Tables (ENIL, 2017a), DE: Wemßen (2014, p. 8); d) Eurostat Population Database (2017). Data of a) and b) relate to the year 2013, data of c) and d) relate to a time range of 2012-2015.

"Institutions for disabled people", while in the same period, the United Kingdom spent more than three quarters for "Assistance in carrying out daily tasks: local authority personal social services" (OECD, 2017a). But the fact that personalisation is not established to the same degree in the countries included in this comparison is the main topic of this article and can be explained theoretically. Nevertheless, the umbrella category is, to the best of my knowledge, the most appropriate comparative measurement for the degree of the welfare state's redistributive social spending for disability care. The other key measurement is the proportion of people receiving personal assistance of the total population. The data comes from the Comparative Survey on Personal Assistance in Europe of ENIL for Switzerland, Sweden, and the United Kingdom, and from Wemßen (2014) for Germany.

One can see that social redistributive spending follows the welfare regime path, as expected, and follows the character of redistributive preferences described by Esping-Andersen (1990). The liberal United Kingdom has the lowest degree of redistributive spending, conservative-corporatist Germany lays in the middle, and social democratic Sweden has the highest degree of redistributive spending. In contrast, the degree of personalisation does not follow the order of having the conservative-corporatist cases between the liberal and social democratic cases. Here, the liberal United Kingdom shows the highest degree of personalisation, followed by social democratic Sweden. In contrast, the personalisation degree of conservative-corporatist Germany is much lower.

Switzerland, as such, seems to be a very interesting case because, as shown in Table 1, its degree of personalisation is even below that of Germany while the redistributive figure is somewhat below, but close to that of Germany. However, Esping-Andersen (1990) classified Switzerland as being part of the world of liberal welfare regimes. In more recent studies, Switzerland is rather classified as a hybrid case, with liberal as well as conservative characteristics (see e.g., Bonoli \& Kato, 2004). Overall, Switzerland is generally hard to classify in comparative social policy (Ciccia, 2017, p. 2762). Considering its long liberal tradition of providing the male and able-bodied part of society with extended civil and polit- ical rights, the low extend of personalisation in Switzerland seems to be a challenge for the theorising of the nexus of welfare regimes and disability care personalisation. Therefore, following Ciccia (2017) the analysis of the hybrid case of Switzerland is now combined with a disaggregated in-depth policy analysis.

\subsection{The Role of the Historical Institutionalization of Disability Services and Disability Organisations}

Strong similarities between Switzerland and Germany are obvious by looking at the organisation of disability services. Aselmeier and Weinbach (2004) compare social services for people with intellectual disabilities in Sweden, England, and Germany. As an example of the social democratic regime, they see in Sweden evidence of a Universalist approach characterised by the provision of access for disabled people to common public welfare services (Aselmeier \& Weinbach, 2004, p. 104). In Sweden specialised services for disabled people just played a limited role (Aselmeier \& Weinbach, 2004, p. 104), thanks to access to universal welfare. Standing for the liberal welfare regime, in England Aselmeier and Weinbach (2004, pp. 104-105) detect Universalist community-based and rights-based policies in the hands of local social services. However, in Germany, as an example of the conservativecorporatist model, one can detect a historical differentiation of specialised social services for disabled people (Aselmeier \& Weinbach, 2004; Rohrmann \& Schädler, 2011). Charities (Wohlfahrtsverbände, private Träger) often organise these specialised social services in a corporatist tie-up with the state (Aselmeier \& Weinbach, 2004, pp. 105-107). According to Aselmeier and Weinbach (2004, p. 105), the actors of these specialised disability services show a strong persistence against the implementation of more flexible services.

Münder (1998, p. 4) defines corporatism in social services as the planned and coordinated intermeshing of voluntary, as well as public, providers of social services with the aim to achieve a common goal. Corporatism within the provision of social services is linked with the welfare regime. While corporatist settings in the economy were decisive both for social democratic as for conservative-corporatist welfare regimes (Esping- 
Andersen, 1990), the social democratic governance of social services follows the principle of strong public services while the Christian democratic governance follows the principle of subsidiarity (Huber \& Stephens, 2000, pp. 325-326). Christian democratic governance of social services prefers the proliferation of social services by diverse stakeholders (families, clerical charities, civil society) to strong public providers with centralised governance (Huber \& Stephens, 2000, pp. 325-326). In Germany, charities with historical ties to the church play an important role in the provision of social services (Münder, 1998) and especially in the provision of disability care (Rohrmann \& Schädler, 2011).

Despite not being similarly influenced by Christian democratic ideas, I argue that we have major similarities in Switzerland regarding the governance of social services. We know from research about other social services that the subsidiarity-oriented governance of social services seems not to be bound to Christian democracy in Switzerland: having the Swiss Christian democrats mostly prevalent in catholic regions, Kersten (2015, chapter 6) outlines a perfect example of subsidiarity-oriented governance of victim counselling services in the protestant canton of Bern.

One can understand the corporatist setting of social services as a historically developed supplement to subsidiarity (Münder, 1998). This is especially true for disability care in Switzerland because disability care institutions were meant to supplement the caring function of the traditional family. Therefore, there are many disability organisations with a history of being established as parental organisations in Switzerland. Since Switzerland is a welfare state latecomer (Häusermann, 2010), the collective organisations of parents had to actively organize in order to convince the state to undertake some of the caring responsibility. Hence, the parents' movement was once a social movement fighting for better distributive justice for their disabled children and collectively fought for special education and residential care institutions in the 1950s, 1960s, and 1970s (see e.g., Insieme Solothurn, 2006, pp. 20-32). Therefore, both, disability organisations with a parents' movement history, as well as the specialized residential care institutions, are today important institutionalised stakeholders in Swiss disability care policy making. The existence of this kind of institutionalised stakeholders and the lack of a strong centralised governance provides a strong degree of corporatism within the field.

\subsection{Limited Opportunities for Contentious Politics and Policy Change in Switzerland}

The central welfare provider for disabled people in Switzerland is called Invalidenversicherung (IV). The Swiss history of the emancipatory push for personal assistance is strongly linked with the IV. After being established in 1996, the Centre for Independent Living Zürich gained momentum in 1997 with an illegal occupation of a public municipal park in Bern, right next to the BSV (the upper supervisory ministry of the IV) for several days (Wehrli, 2012). This protest provoked huge media response and support of local residents and forced the ministry to enter into dialogue with the protesters (Wehrli, 2012). In 1999, another emancipatory organisation called Fachstelle Assistenz Schweiz (FAssiS) was founded by Katharina Kanka, which organised several demonstrations and vigils (Wehrli, 2012). As result of this contentious process, the emancipatory activists were invited to a bargaining process with already institutionalised stakeholders and with policy makers, which was initiated and moderated by the BSV. On one hand, this kind of corporatist conflict moderation gave the emancipatory activist quite early access to the bargaining table. On the other hand, their abilities for further contentious actions were limited and they were forced to find coalitions with existing institutionalised stakeholders and political parties.

The likely alliance with the liberals seemed to be successful at first. Having encountered major issues in forming coalitions with the social democrats, the activists relied on the ideological support of centre-right and right-wing politicians, who openly admitted to being interested in the ability of personalisation in order to transform responsibility and reduce costs (Wehrli, 2012). This ideological support put the centre-left parties under pressure and later helped Katharina Kanka to form a multipartisan group of supporters of a personalisation reform which was also consistent with leftist and centre-left politicians. However, the then-established orthodoxy that social expenditure after the personalisation reform should be lower or at least cost-neutral was decisive for further development. In 2006, a pilot program for personal assistance was started but could not be implemented in a cost-neutral manner (Flückiger, 2011, p. 73). Mainly the non-monetized care work of relatives was, to some extent, a cost driver because this kind of work started to be monetised in the personalisation pilot (Flückiger, 2011, p. 74). The encounter with the unpaid (and mostly female) care work made it impossible for the pilot program to satisfy its orthodoxy of cost reduction. With these results, the possibility of a profound liberal reform was minimised. In addition, the simultaneous push of right-wing politicians for austerity measures within the disability pension scheme of the IV produced an additional obstacle for the activists (Wehrli, 2012). A further hindrance was the fact that within the bargaining process, the governance of disability services was further transferred to the cantonal level because of a new cantonal fiscal equalization scheme: Neuer Finanzausgleich (Flückiger, 2011, p. 45). Overall, the opportunity for a policy coalition with liberal forces for a profound policy change was restricted.

In the bargaining process, it was as much decisive that the other likely allies, the Swiss social democrats, were very sceptical about the claims of the emancipatory activists (Wehrli, 2012). The position of the so- 
cial democrats in the early 2000s can be understood by looking at the corporatist settings of disability service providers and disability organisations with which they were aligned. First, the syndicates of the disability care institutions, mainly INSOS (syndicate of disability care institutions) and Curaviva (syndicate of all care institutions, including those for the elderly), are important players within the field of disability care. These syndicates have traditionally strong ties with social democratic politicians. Second, the social democrats have traditionally strong ties with institutionalised disability organisations. For the emancipatory activists, however, the influence of the historically grown parents' organisations proved to be very challenging. The parents' organisations opposed major claims of the emancipatory movement and particularly argued for the continuance and protection of institutional care in the field of intellectual disability (Wehrli, 2012). Third, a social democratic policy maker earns praise by joining the board of trustees (Stiftungsrat) of a disability care institution as an unpaid member. Being part of such a board provides the politician with an inside overview of the challenges the institutional provider faces but does not provide the politician with a critical look from the outside at the parameters being set up by institutionalisation. Fourth, the orthodoxy of cost-neutrality prevented a possible coalition with the trade unions of care workers and therefore the formation of a progressive left-leaning coalition for personal assistance. For the trade syndicate, the underlying ideas of cost reduction were deplorable and the proposed wages for personal assistants unsatisfactory (VPOD, 2009). In closing, the Swiss social democrats were, on this issue, more strongly influenced by their ties with certain actors and institutions rather than by their ideas of universalism and equality. Overall, the opportunity for policy coalitions with social democratic forces for profound policy change was restricted.

Since January 1, 2012, the IV has provided an official contribution called Assistenzbeitrag, which allows people to employ personal assistants (Egloff, 2017). In practical terms, this personal assistance system mostly includes people older than 18 , with a strong focus on people with physical disabilities (Büro BASS, 2017, pp. 22, 73). This system is means-tested and has a strict and long assessment procedure one has to actively initiate. The Swiss government projects the dropouts of residential care institutions to not be greater than $10 \%$ in the long run (Egloff, 2017, pp. 133-142, see the full book for a substantive qualitative in-depth analysis regarding this phenomenon).

\subsection{Stability through Institutionalised Status Inequalities: Or Bringing Regime Theory Back In}

I now return to regime theory. The possibility to analyse the effects of a bundle of policies rather than single policies represents a major advance of regime theory (Ciccia, 2017, pp. 2763-2764). I argue that the emergent effect produced by the Swiss disability care policy bundle is the best explanation for the current state of art in Swiss disability care policy.

Overall, the Swiss welfare state is a historically matured multilayer system, being predominantly Bismarckian while simultaneously relying on other diversely structured social policy systems (Häusermann, 2010, pp. 211-212). The IV, which was established in 1960 has Bismarckian characteristics. The Bismarckian social legislation had a significant impact on the ideas of the Swiss political elites at the beginning of the 20th century (Lengwiler, 2007, p. 50). However, the high degree of federalism in Switzerland and social-legislation hindering referenda made the coherent implementation of the Bismarckian social legislation unachievable (Lengwiler, 2007, pp. 55-60). On the other hand, the Beveridge approach, which provided an alternative to Bismarckian social insurance, was heavily debated in 1943 in Switzerland but was rejected by important interest groups (Degen, 2006, p. 33). This led to the establishment of a mixed, but overall Bismarckian system in the golden years of welfare state expansion after the Second World War. Regarding the eligible population, the IV is not genuinely Bismarckian, although its procedures for benefit-assessments are highly influenced by Bismarckian ideas.

Bismarckian social policy was never intended to support societal change; rather, its purpose is to conserve societal class and status structures. It is aimed to protect societal groups from the market, but does not aim to significantly change the relations between societal groups. This conservative stratification tradition seems to be a stabiliser for residential care in Switzerland: the personal assistance system is mainly designed for disabled people, who already have middle-class skills and a middleclass consciousness. The assessment procedure is particularly designed for these people and does not empower other people to gain a middle-class right and middleclass skills. Therefore, the stability of the existing residential care path is maintained by institutionalised status inequalities. It provides access to personal assistance only to those people who are successful in the assessment procedure thanks to their skills of rights claiming, and simultaneously hampers the energy of the disability activists with the most potential to conduct contentious actions. Overall, the Swiss personal assistance system allows the stability of residential care facilities and simultaneously provides pacification of possible emancipatory protests.

\section{Conclusion}

Within this heuristic undertaking, we have seen that the analysis of bivalent social justice is helpful for theorising personalisation. The evolvement of disability rights following a path of nonlinear distribution of both kinds of justice led to the claim for more recognition justice through emancipatory movements (Fraser, 2013). According to Fraser (2013), emancipatory movements are 
aiming to overcome oppressive social protection and they can possibly ally with marketization forces or with (new) forces of social protection. However, this article analysed a case in which none of these possible alliances occurred profoundly. I argued that conservativecorporatist disability care cases have a strong institutionalisation of oppressive social protection and benevolent paternalism. We verified that in the case of Switzerland, this setting could not (yet) be profoundly transformed by forces of emancipation. In this respect, the case of Switzerland did prove to be illuminating. Switzerland seems to resemble conservative-corporatist cases in the field of disability care. Therefore, the Swiss case provides some insights on the process of limited personalisation of disability care in continental European countries. Furthermore, the analysis of the characteristics of Switzerland in this policy field is a contribution to welfare regime research.

Nonetheless, some limitations have to be mentioned as well. First, this analysis lacks the potential to provide general evidence for all continental European countries. Instead, it only provides evidence that the developments in Switzerland have been shaped by continental European conservative-corporatist specificities. Second, the influence of the welfare regime as an opportunity structure may decrease in the future because of transnationalisation (Sturm, Waldschmidt, Karačić, \& Dins, 2017). Article 19 of the UN Convention on the Rights of Persons with Disabilities will particularly provide an important tool for political actors who aim to increase independent living. Third, this analysis is only a heuristic approach. Further theoretical and empirical insights of personalisation in continental European countries would be highly desirable.

\section{Acknowledgement}

I owe special thanks to Justin J. W. Powell for his support and assistance and for his excellent comments and advice. Furthermore, I would like to thank all participants of the Doctoral Program PROWEL Social Problems and Welfare, Switzerland, in May 2017, for their helpful comments and suggestions regarding an early version of this article. Similarly, many thanks to all participants at the meeting of the Institute for Education and Society, University of Luxembourg, in October 2017, for their helpful comments and suggestions regarding a more advanced version of this article. All remaining omissions and mistakes are my sole responsibility. I acknowledge the Swiss National Science Foundation (SNSF) for the funding of the research as well as for the funding of the open access publication fee. Both are provided through a Doc.CH grant (Number 172008).

\section{Conflict of Interest}

The author declares no conflict of interest.

\section{References}

ANED. (2009). The implementation of policies supporting independent living for disabled people in Europe: Synthesis report (VT/2007/005). Brussels: Academic Network of European Disability Experts.

Aselmeier, L. (2008). Community Care und Menschen mit geistiger Behinderung: Gemeinwesenorientierte Unterstützung in England, Schweden und Deutschland. Wiesbaden: VS Verlag für Sozialwissenschaften.

Aselmeier, L., \& Weinbach, H. (2004). Drei Welten der Hilfen für Menschen mit Behinderung? Unterstützung für Menschen mit geistiger Behinderung aus der Perspektive vergleichender Wohlfahrtsforschung. In K. Grebe \& J. Schädler (Eds.), Sorge und Gerechtigkeit: Werkleute im sozialen Feld (pp. 95-112). Frankfurt: GAFB-Verlag

Barnartt, S., \& Scotch, R. (2001). Disability protests. Contentious politics 1970-1999. Washington, DC: Gallaudet University Press.

Baumgartner, E. (2008). Verheissungen von Assistenzmodellen für Menschen mit Behinderung. Eine Diskussion von Beispielen und Erkenntnissen aus Europa. Schweizerische Zeitschrift für Soziale Arbeit, 2008(5), 83-104.

Baumgartner, E. (2009). Das Persönliche Budget im internationalen Vergleich: Erfahrungen in Schweden, den Niederlanden, Großbritannien und der Schweiz. Archiv für Wissenschaft und Praxis der sozialen Arbeit, 40(1), 78-89.

Beresford, P. (2014). Personalisation: From solution to problem? In P. Beresford (Ed.), Personalisation (pp. 1-26). Bristol: Policy Press.

Bonoli, G., \& Kato, J. (2004). Social policies in Switzerland and Japan: Managing change in liberal-conservative welfare states. Swiss Political Science Review, 10(3), 211-232. https://doi.org/10.1002/j.16626370.2004.tb00037.x

BSV. (2007). Assistenzmodelle im internationalen Vergleich. Leistungen und Massnahmen zur Unterstützung selbstbestimmten und eigenverantwortlichen Lebens in ausgewählten Ländern (Forschungsbericht $\mathrm{nr}$. 11/07). Bern: Bundesamt für Sozialversicherungen.

Budowski, M., \& Schief, S. (2017). Strategies of households in precarious prosperity in Chile, Costa Rica, Spain and Switzerland. In J. Mackert \& B. S. Turner (Eds.), The transformation of citizenship, volume 1: Political economy (pp. 167-187). Abingdonon-Thames: Routledge.

Büro BASS. (2017). Evaluation Assistenzbeitrag 20122016 (Forschungsbericht nr. 8/17). Bern: Büro für arbeits- und sozialpolitische Studien.

Charlton, J. (2010). The dimensions of disability oppression. In L. J. Davis (Ed.), The disability studies reader (3rd ed., pp. 147-159). Abingdon-on-Thames: Routledge.

Christensen, K., Guldvik, I., \& Larsson, M. (2014). Active social citizenship: The case of disabled peo- 
ples' rights to personal assistance. Scandinavian Journal of Disability Research, 16(sup1), 19-33. https:// doi.org/10.1080/15017419.2013.820665

Ciccia, R. (2017). A two-step approach for the analysis of hybrids in comparative social policy analysis: A nuanced typology of childcare between policies and regimes. Quality \& Quantity, 51(6), 2761-2780. https://doi.org/10.1007/s11135-016-0423-1

Degen, B. (2006). Entstehung und Entwicklung des schweizerischen Sozialstaates. Studien und Quellen (pp. 17-48). Bern: Schweizerisches Bundesarchiv.

Dodd, S. (2016). Orientating disability studies to disablist austerity: Applying Fraser's insights. Disability \& Society, 31(2), 149-165. https://doi.org/ 10.1080/09687599.2016.1152952

Drake, R. F. (1999). Understanding disability policies. Houndmills: Palgrave Macmillan. https://doi.org/ 10.1007/978-1-349-27311-9

Ebbinghaus, B. (2015). Machtressourcentheorie und Korporatismusansatz. In G. Wenzelburger \& R. Zohlnhöfer (Eds.), Handbuch Policy-Forschung (pp. 55-79). Wiesbaden: Springer VS. https://doi.org/ 10.1007/978-3-658-01968-6_3

Egloff, B. (2017). Selbstbestimmt unterstützt durch Assistenz. Eine empirische Untersuchung zur Einführung und Umsetzung des Assistenzbeitrags in der Schweiz. Bern: Edition SZH/CSPS.

ENIL. (2017a). Personal assistance tables from the comparative survey on PA in Europe. European Network on Independent Living. Retrieved from http:// enil.eu/policy/personal-assistance-tables

ENIL. (2017b). The right to live independently and be included in the community. Addressing barriers to independent living across the globe. Brussels: European Network on Independent Living.

ESN. (2013). Independent living: Making choice and control a reality. An ESN report on how social services in Europe are promoting choice and control alongside people with disabilities. Brighton: European Social Network.

Esping-Andersen, G. (1990). The three worlds of welfare capitalism. Cambridge: Polity Press.

Eurostat Population Database. (2017). Population on 1 January. Eurostat. Retrieved from http://ec.europa. eu/eurostat/tgm/table.do?tab=table\&init=1\&plugin $=1 \&$ language $=$ en $\&$ pcode $=$ tps 00001

Flückiger, S. (2011). "...Er ist schon mein Chef, aber es ist ein ganz anderes Gefühl.": Theoretische Analyse und empirische Erkundung der Anforderungsstruktur von Assistenzsettings (Master thesis). Department for Special Education, University of Fribourg, Fribourg.

FRA. (2013). Choice and control: The right to independent living. Experiences of persons with intellectual disabilities and persons with mental health problems in nine EU Member States. Vienna: European Union Agency for Fundamental Rights.

Fraser, N. (2003). Social justice in the age of identity politics: Redistribution, recognition, and participation.
In N. Fraser \& A. Honneth (Eds.), Redistribution or recognition? A political-philosophical exchange (pp. 7-109). London: Verso.

Fraser, N. (2013). A triple movement? Parsing the politics of crisis after Polanyi. New Left Review, 81, 119-132.

Fraser, N., \& Honneth, A. (2003). Redistribution or recognition? A political-philosophical exchange. London: Verso.

Häusermann, S. (2010). Reform Opportunities in a Bismarckian Latecomer: Restructuring the Swiss welfare state. In B. Palier (Ed.), A long goodbye to Bismarck? The politics of welfare reforms in continental Europe (pp. 207-231). Amsterdam: Amsterdam University Press. https://doi.org/10.5117/9789089642349

Huber, E., \& Stephens, J. D. (2000). Partisan governance, women's employment, and the social democratic service state. American Sociological Review, 65(3), 323-342. https://doi.org/10.2307/2657460

Insieme Solothurn. (2006). Vom Rand in die Mitte. 40 Jahre Insieme Solothurn. Grenchen: Insieme Solothurn. Retrieved from http://www.insiemesolothurn.ch/uploads/media/festschrift_insieme_jan _2006.pdf

Kersten, A. (2015). Opferstatus und Geschlecht. Entwicklung und Umsetzung der Opferhilfe in der Schweiz. Zürich: Seismo Verlag.

Knight, A. (2015). Democratizing disability: Achieving inclusion (without assimilation) through "participatory parity". Hypatia, 30(Winter 2015), 97-114. https://doi.org/10.1111/hypa.12120

Lengwiler, M. (2007). Transfer mit Grenzen: Das “Modell Deutschland" in der schweizerischen Sozialstaatsgeschichte (1880-1950). In G. Kreis \& R. Wecker (Eds.), Deutsche und Deutschland aus Schweizer Perspektiven (pp. 47-66). Basel: Schwabe Verlag.

Mansell, J., \& Beadle-Brown, J. (2010). Deinstitutionalisation and community living: Position statement of the comparative policy and practice special interest research group of the international association for the scientific study of intellectual disabilities. Journal of Intellectual Disability Research, 54(2), 104-112. https://doi.org/10.1111/j.1365-2788.2009.01239.x

Marshall, T. H. (1950). Citizenship and social class and other essays. Cambridge: Cambridge University Press.

Maschke, M. (2007). Behinderung als Ungleichheitsphänomen: Herausforderung an Forschung und politische Praxis. In A. Waldschmidt \& W. Schneider (Eds.), Disability Studies, Kultursoziologie und Soziologie der Behinderung: Erkundungen in einem neuen Forschungsfeld (pp. 299-320). Bielefeld: Transcript. https://doi.org/10.14361/9783839404867-013

Mladenov, T. (2012). Personal assistance for disabled people and the understanding of human being. Critical Social Policy, 32(2), 242-261. https://doi.org/ $10.1177 / 0261018311430454$

Mladenov, T. (2016). Disability and social justice. Disability \& Society, 31(9), 1226-1241. https://doi.org/ $10.1080 / 09687599.2016 .1256273$ 
Mladenov, T., Owens, J., \& Cribb, A. (2015). Personalisation in disability services and healthcare: $A$ critical comparative analysis. Critical Social Policy, 35(3), 307-326. https://doi.org/10.1177/ 0261018315587071

Münder, J. (1998). Von der Subsidiarität über den Korporatismus zum Markt? Neue Praxis. Zeitschrift für Sozialarbeit, Sozialpädagogik und Sozialpolitik, 18(1), 3-12.

OECD. (2017a). Social expenditure database. OECD.Stat. Retrieved from http://stats.oecd.org/index.aspx? DatasetCode=SOCX_DET\#

OECD. (2017b). National Accounts. OECD.Stat. Retrieved from http://stats.oecd.org/Index.aspx? DatasetCode $=$ SNA_TABLE1\#

Owens, J., Mladenov, T., \& Cribb, A. (2017). What justice, what autonomy? The ethical constraints upon personalisation. Ethics and Social Welfare, 11(1), 3-18. https://doi.org/10.1080/17496535.2016.1234631

Polanyi, K. (2001). The great transformation. The political and economic origins of our time. Boston: Beacon Press. (Original work published 1944)

Powell, J. J. W. (2006). Special education and the risk of becoming less educated. European Societies, 8(4), 577-599. https://doi.org/10.1080/ 14616690601002673

Ratzka, A. (2004). Model national personal assistance policy. Independent Living Institute. Retrieved from http://www.independentliving.org/docs6/ratzka200 410a.html

Richardson, J. G., \& Powell, J. J. W. (2011). Comparing special education: Origins to contemporary paradoxes. Stanford, CA: Stanford University Press. https://doi.org/10.11126/stanford/9780804760737. 001.0001

Rimmerman, A. (2017). Disability and community living policies. Cambridge: Cambridge University Press. https://doi.org/10.1017/9781316493045

Rohrmann, A., \& Schädler, J. (2011). Von der Anstaltsfürsorge zur Assistenz. Soziale Dienste im Feld der Unterstützung von Menschen mit Behinderungen. In A. Evers, R. G. Heinze, \& T. Olk (Eds.), Handbuch Soziale Dienste (pp. 425-441). Wiesbaden: VS Verlag für Sozialwissenschaften. https://doi.org/10.1007/978-3-53192091-7_22

Rummery, K. (2011). A comparative analysis of personalisation: Balancing an ethic of care with user empowerment. Ethics and Social Welfare, 5(2), 138-152. https://doi.org/10.1080/17496535.2011.571064

Samuel, R., \& Hadjar, A. (2016). How welfare-state regimes shape subjective well-being across Europe. Social Indicators Research, 129(2), 565-587. https:// doi.org/10.1007/s11205-015-1125-0

Šiška, J., Beadle-Brown, J., Káňová, Š., \& Tøssebro, J. (2017). Active citizenship through community living: A multi-level perspective. In R. Halvorsen, B. Hvinden, J. Bickenbach, D. Ferri, \& A. M. Guillén Rodriguez
(Eds.), The changing disability policy system. Active citizenship and disability in Europe (Vol. 1, pp. 72-89). Abingdon-on-Thames: Routledge.

Slasberg, C., \& Beresford, P. (2015). Building on the original strengths of direct payments to create a better future for social care. Disability \& Society, 30(3), 479-483. https://doi.org/10.1080/09687599. 2015.1007672

Soldatic, K. (2013). The transnational sphere of justice: Disability praxis and the politics of impairment. Disability \& Society, 28(6), 744-755. https:// doi.org/10.1080/09687599.2013.802218

Soldatic, K., \& Grech, S. (2014). Transnationalising disability studies: Rights, justice and impairment. Disability Studies Quarterly, 34(2). https://doi.org/10.18061/ dsq.v34i2.4249

Sturm, A., Waldschmidt, A., Karačić, A., \& Dins, T. (2017). Exercising influence at the European level: Political opportunity structures for disability rights advocacy and the impact of the UN CRPD. In R. Halvorsen, B. Hvinden, J. Bickenbach, D. Ferri, \& A. M. Guillén Rodriguez (Eds.), The changing disability policy system. Active citizenship and disability in Europe (Vol. 1, pp. 159-176). Abingdon-on-Thames: Routledge.

Swaton, S. (2017). Introduire le concept de personne en économie? Des capabilités au care: Réciprocité et responsabilité. Éthique et économique/Ethics and Economics, 14(1), 11-23.

Tarrow, S. G. (2011). Power in movement. Social movements and contentious politics (Vol. 3). Cambridge: Cambridge University Press. https://doi.org/ 10.1017/CBO9780511973529

VPOD. (2009). Vernehmlassungsvorlage 6. IV-Revision: Stellungnahme des vpod zum Teil "Assistenzbeitrag". Bern: VPOD Zentralsekretariat. Retrieved from http://www.zslschweiz.ch/z_alteseite/Archiv/PDF/ Vernehmlassung\%206.\%20IVG\%20Revision_vpod.pdf

Waldschmidt, A. (2009). Disability policy of the European Union: The supranational level. ALTER: European Journal of Disability Research/Revue Européenne de recherche sur le handicap, 3(1), 8-23. https:// doi.org/10.1016/j.alter.2008.12.002

Waterplas, L., \& Samoy, E. (2005). L'allocation personnalisée: Le cas de la Suède, du Royaume-Uni, des PaysBas et de la Belgique. Revue française des affaires sociales, 2005(2), 61-101.

Wehrli, P. (2012). Geschichte der Persönlichen Assistenz in der Schweiz. Retrieved from http://www. assistenzforum.ch/viewtopic.php? $\mathrm{f}=3 \& \mathrm{t}=71$

Wehrli, P. (2016). Selbsthilfe. In I. Hedderich, G. Biewer, J. Hollenweger, \& R. Markowetz (Eds.), Handbuch Inklusion und Sonderpädagogik (pp. 528-532). Bad Heilbrunn: Julius Klinkhardt.

Wemßen, F. (2014). Das persönliche Budget. Entwicklungsstand in Deutschland und im europäischen Ausland. Sozial Extra, 3, 6-9. https://doi.org/10.1007/ s12054-014-0056-3 


\section{About the Author}

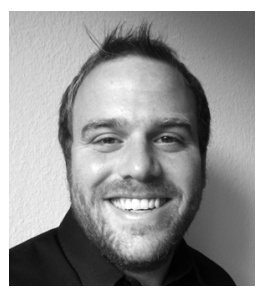

Christoph Tschanz is a PhD candidate at the University of Fribourg, Switzerland, where he works at the Division of Sociology, Social Policy, and Social Work funded by a Doc.CH grant provided by the SNSF. Part of this analysis was conducted during a stay as visiting PhD candidate at the Institute of Education \& Society (InES), at the University of Luxembourg. He is specialising in comparative perspectives on European disability policies. Christoph holds a Master's degree in Sociology and a Bachelor's degree in Remedial Education and Social Pedagogy, both from the University of Fribourg. He previously worked as a social pedagogue in a supported employment program for people with an autism-spectrum condition. 